\title{
Evolution and the Prevention of Violent Crime
}

\author{
Jason Roach ${ }^{1}$, Ken Pease ${ }^{2}$ \\ ${ }^{1}$ Huddersfield University, Huddersfield, UK; \\ ${ }^{2}$ Loughborough University, Loughborough, UK. \\ Email: j.roach@hud.ac.uk \\ Received April 28 ${ }^{\text {th }}$, 2011; revised June $2^{\text {nd }}$, 2011; accepted July $3^{\text {rd }}, 2011$.
}

\begin{abstract}
This paper suggests how violence prevention can be better informed by embracing an evolutionary approach to understanding and preventing violent crime. Here, ethical crime control through an evolutionary lens is considered and speculation is offered as to what an evolution-evidenced crime reduction programme might look like. The paper begins with an outline of the current landscape of crime prevention scholarship within criminology and presents some possible points of contact with actual or possible violence reduction practice, including child homicide and violence against women. The paper concludes with suggestions for an ethical research agenda for reducing violence, whereby it is hoped that an audience of open-minded criminologists and diverse students of evolution may lend a hand in increasing the sophistication of the criminological study of violence prevention.
\end{abstract}

Keywords: Violence, Evolution, Child Homicide, Prevention

\section{Introduction}

Criminology generally is justly criticized for its theoretic insularity, and in particular its general hostility towards or neglect of approaches other than that of sociological determinism (Pease, 2010; Roach and Pease, in press). Its journals tend to be titled according to geography or methodological focus (e.g. European Journal of Criminology, Journal of Quantitative Criminology). There are few cross-discipline titles characteristic of faster-advancing disciplines, and cited references tend to be older and more often book based than one finds in livelier branches of scholarship. When one of the present authors told a distinguished professor of mainstream criminology that he was co-writing the present paper, the reply was a derisive "You're better than that".

Insofar as systematic attempts at crime reduction take their theory from academic criminology, evolutionary perspectives are therefore predictably marginal or absent. In the near eight hundred pages of Nick Tilley's authoritative edited "Handbook of Crime Prevention and Community Safety” (Tilley, 2005), evolution is mentioned once, in a chapter by the second author (Pease, 2005). It is not mentioned at all elsewhere, even in the chapter on violent and sexual crime (Maguire \& Brookman, 2005). It would be tedious to rehearse the absence of evolution as a topic from all other leading recent texts on crime prevention, such as Welsh and Farrington (2006) and Tilley (2010). Attempts to translate evolutionary insights into social policy have an unhappy history. Many social scientists may thus feel it prudent to avoid such contributions as it may make. For example, in 2008 when the authors asked attendees at the British Society of Criminology annual conference to complete a short questionnaire asking for their opinion on the utility of evolutionary thinking in criminology, only a derisory fifteen per cent condescended to do so, and most of those who did, considered it to be irrelevant to criminology.

Tooby and Cosmides (1990) define evolutionary psychology as, psychology which centres on the fact that the structure of the human mind, which has been inherited, and represents the product of evolutionary processes (i.e. natural and sexual selection). Put more simply, what we can do today is a direct result of what was needed to be done in order to increase our ancestors' survival and reproductive chances in the past. What as humans we are able to do today, therefore, is a direct result of the evolution of our species-namely how our ancestors adapted to their environment. Genes being simply the method of transmission between generations.

Evolutionary psychologists seek "functional” explanations for behaviour. For example, why a particular human behaviour, ability or characteristic has evolved, and not causal explanations, focused on immediate precursors or causes of that behaviour, in the environment in which it occurs (Smith \& Stevens, 2002). This is a rapid departure from, for example, behaviourist psychology and environmental criminology, where it is the immediate environment which is of primary focus. Evolutionary psychologists focus instead on the distant past, attempting to locate the function of certain behaviours in our evolutionary past by looking at our ancestors. Smith and Stevens (2002), for example, pose the question, why is it human beings have evolved spoken language when other close primates, such as chimpanzees, have not? Many other aspects of chimpanzee physiology (including a 95\% DNA match) are similar, so what were the evolutionary pressures that supported the ability to develop and use language in humans only? Evolutionary psychologists adopt reverse engineering in seeking answers to questions such as this (Tooby \& Cosmides, 1990).

An evolutionary informed criminology of the sort called for in this article, should consider how distal factors (such as displays of aggression related to sexual competition and fitness among young men) interact with the more proximal (e.g. crowded, noisy bars full of young men) and how this can inform violence prevention strategies and interventions. We call for an "Evolutionary informed criminological" approach to violence, which, therefore, considers how distal and proximal factors contribute and interact when explaining (and preventing) 
criminal behaviour, referred to as Gene $\times$ Environment $(G \times E)$ effects. Caspi and colleagues' wonderful example of the interaction between expression of the MAOA gene and violent behaviour is presented later in the article (Caspi et al., 2002).

Eugenics and social Darwinism apart, the central objection of criminologists to accepting evolutionary insights seems to be that crime, including violent crime, is a social construct, and explaining a socially constructed phenomenon in biosocial or evolutionary terms constitutes a category error. This objection is not a powerful one. To adopt and adapt the Gottfredson and Hirschi (1990) characterization in their general theory, crime can be seen as actions seeking to gain advantage over conspecifics by force or fraud. Minor definitional tweaking is necessary to exclude sanctioned combat sport and warfare, but the vast bulk of criminal law reflects this, consisting of more or less tightly worded proscriptions of intra-species advantage-taking by force or fraud. Violent crime represents the first of these means of securing advantage. This is not of course to say that most attempts to gain advantage by force or fraud are treated, still less processed, as breaches of criminal law. More such attempts probably occur in a day's playground bullying or questionable sales techniques than in a century's processed crimes, even in societies that would see themselves as governed by the rule of law. Neither is it the case that law is equally applied cross-nationally, with violence against women representing a particularly troubling case in point (see Weldon, 2002). There are tautologies involved in the linkage of evolutionary thought and what counts as a crime. Criminal law is enacted for forms of behaviour which are deemed to be too serious or disruptive of social order to be dealt with by citizens informally or via civil law. There is no need to enact criminal laws in respect of behaviours which no-one wants to perform, or which harm only the behaver. There is no law against coprophagia, for example. Matters are more complex than this, given a religious underpinning to the criminal law which has in the past forbidden suicide, for instance. Nonetheless, it is tenable to assert that criminal law proscribes those actions which selection pressures of the environment of evolutionary adaptedness (EEA) gave some or all of us the inclination to perform, as the EEA-derived equivalent of Original Sin. Insofar as this is the case, crime reduction constitutes an attempt to curb or sublimate evolution-derived predatory actions. As Owen Jones (2005) notes, law is "a tool for moving human animals to behave in ways they would not otherwise behave if left solely to their own devices” (p. 953). Of course this also applies to education and regulated sport, as well as to the behaviour of both the offender and the preventer. Jones framed the "law of law's leverage" as follows

"The magnitude of legal intervention necessary to reduce or to increase the incidence of any human behaviour will correlate positively or negatively, with the extent to which such a predisposition contributing to that behaviour was adaptive for its bearers, on average, in past environments” (p. 962)

Save for a quibble with the insertion of legal as the fourth word in Jones' law (since most effective interventions seem to consist in the manipulation of opportunities rather than weight of legal response) the point is well made. That said, criminal law has to be seen as an attempt to produce behaviour different from what it would be were selection pressures to have their way unimpeded. Effective laws against murder or dangerous driving, for example, alter selection advantage for those who do not waste their reproductive years in prison (and careful pedestrians). This, of course, represents a crude position. And the application to problems of violent crime of memetics as a form of evolutionary thinking would yield a more sophisticated perspective. Indeed, a wholly different perspective could be taken on the issue by concentrating on enhancing cooperation rather than reducting its antithesis, agonistic behaviour. While this approach was seriously considered, given the extensive current work from that perspective (see for example Nowack, 2011) it was rejected for no better reason that the length of the piece was already unwieldy and the deadline for its submission past.

Having thus excluded the option of "accentuating the positive" in favour of seeking to "eliminate the negative"1 what, then, can the present article hope to contribute? It aspires (very diffidently) to consider ethical crime control through an evolutionary lens, and thereby to invite the deployment of evolution insights in criminology journals and crime reduction practice, and to speculate what an evolution-evidenced crime reduction programme might look like. To that end, it will

1) Outline the current landscape of crime prevention scholarship within criminology, with the hope of eliciting contributions from those with expertise in evolution science; and

2) Present some possible points of contact with actual or possible violence reduction practice, by reference to extant literature in evolutionary psychology and criminology.

The hoped for audiences are open-minded criminologists and diverse students of evolution who may lend a hand in increasing the sophistication of the criminological study of violence prevention. Given these aims, it is perhaps inevitable that some ideas will be seen as banal, others as tendentious. Successful crime reduction approaches must, arguably, be conistent with evolutionary thought, otherwise they would not have been successful. To anticipate a conclusion, attempts to change those embarked upon a criminal career based upon presumptions of pathology enjoy limited success relative to those based upon common perceptions of crime opportunities. Evolutionary insights are sought primarily in relation to how people understand and respond to violence-precipitating situations.

In what follows, violent crime prevention refers to the preclusion, by ethically defensible means, of individual violent offending acts. Harm reduction involves the reduction of harmful consequences in unprevented violent acts.

Crime reduction: the state of the art.

The conventional classification of crime reduction distinguishes primary, secondary and tertiary methods. This bestknown categorization was devised by Brantingham and Faust (1976). Primary prevention reduces crime opportunities without reference to characteristics of criminals or potential criminals. Secondary prevention seeks to change people, typically those at high risk of embarking upon a criminal career. Tertiary prevention works by the truncation of a criminal career, in length, seriousness, or frequency of offending. The Brantingham and Faust classification was later refined by Van Dijk and de Waard (1991) and remains useful. Primary prevention has focused upon proximal causes or precipitators of the crime event, and can be criticized for neglect of distal 'causes'. However, this is a matter of convenience and immediate utility, rather than being

\footnotetext{
${ }^{1}$ And not "messing with Mr. In-Between", as enjoined in the Johnny Mer-
} cer-Harold Arlen song. 
intrinsic in the definition. Primary prevention simply assumes a supply of motivated potential offenders, and changes the circumstances which realize the latent criminality. While this has typically involved place design, hot spot management, and other such factors, it does not in logic exclude structural factors of evolutionary interest, such as the gender composition of populations. Indeed, the origins of routine activity theory, which underpins much primary prevention, lie in the linkage of distal factors such as the lengthening of childhood dependency and general access to goods. Thus primary prevention is here used to include all approaches which are person-neutral, i.e. which does not seek or target individuals according to their present or predicted criminality. Primary prevention also sits more easily with the public health perspective favoured by the World Health Organisation (see Krug et al., 2002).

Primary crime prevention has some advantages over rival approaches in terms of the weight of evidence brought to bear in its support, and in terms of the slightness of the level of social engineering often necessary for its implementation in its proximal form. Underpinning the approach, as noted above, is the routine activities theory of Marcus Felson (2002), in which an offender who is ready, willing and able encounters, seeks out or engineers a crime situation comprising a vulnerable and attractive target of crime, in a favourable environment and in the absence of motivated and capable preventers. Routine activities theory was initially developed to address the paradox of increased urban violence at a time when social conditions deemed relevant improved (Cohen \& Felson, 1979). These authors saw predatory crime as a by-product of routine activities, in particular the dispersion of activities away from home and family.

If crime, especially violent crime, is simply the natural work of evil or damaged people, then convicting and incapacitating evil and damaged people lies at the heart of police work. For those of the left politically, the emphasis is on the remediation of damage to the person, deemed to have been occasioned through deprivation of one kind or another. Marcus Felson (1994) refers to this as the "pestilence fallacy", which asserts that bad things come from other bad things. He writes:

Why was the major period of crime rate increase in the United States 1963 to 1975, also a period of healthy economic growth and relatively low unemployment? Why did Sweden's crime rates increase greatly as its Social Democratic government brought more and more programmes to enhance equality and protect the poor? (pp. 11-12).

Felson concludes that "crime seems to march to its own drummer", and that the richness of crime opportunities is the crucial factor which determines the beat. This is a conclusion of fundamental importance for crime reduction, suggesting that the regulation of the supply of crime opportunities is central to the reduction enterprise.

The common criticism by scholars in the biological sciences of the application of evolutionary ideas to behaviour and its regulation is best known as simply retailing "Just So" stories, speculative and unconstrained by evidence (see for example Coyne, 2009). Our riposte is that much of criminology has consisted of Just-So stories of sociological origin, to the point where the discipline of criminology is fragmented and possibly in terminal decline (see for example Loader \& Sparks, 2010). If evolutionary concepts turn out to have no more than heuristic value in designing research and crime-reductive practice, it will be no worse than what has gone before. If it turns out that successful crime reduction can be derived from and is consistent with such concepts, a new direction for criminology will have been signposted. Co-evolution has already been used as a simile for the "arms race" between offenders and purveyors of primary prevention (Ekblom, 1997, 1999), ${ }^{2}$ and some primary prevention techniques have apparently been inspired by animal defence mechanisms, for example the squid's deployment of opaque fluid when under attack. ${ }^{3}$ Felson (2006) devotes a chapter of his book "Crime and Nature" to "Crime's First Defences". Understanding offender foraging behaviour has informed optimal police deployment (Johnson et al., 2009).

\section{Primary Violent Crime Prevention: Can Evolutionary Thinking Contribute?}

The renowned astrophysicist Stephen Hawking argued in April 2010 that we should avoid making contact with extraterrestrial life forms. The media reported this in somewhat xenophobic terms (if that word can be applied to extra-terrestrials). The more misanthropic truth was revealed by his remark that "We only have to look at ourselves to see how intelligent life might develop into something we wouldn't want to meet."

As Buss and Shackelford (1997) point out, the ubiquity of human violence cannot be explained solely by the variables of usual criminological interest. Although of no little importance, the question whether violence has roots as an adaptive strategy that once increased reproductive success, it is not the brief for this article, it being specifically about prevention. The age crime curve and the preponderance of male violence are perhaps the two central facts about the distribution of criminality. Self-reported and recorded offending, both violent and other, peak in the late teens and are higher for males at every age. The claim that the age-crime relationship is invariant across epoch and culture (Hirschi \& Gottfredson, 1983) is roughly true, with the exceptions being of equal interest as the generality. For example Zhong (2005) showed that in a period of rapid economic development in Taiwan, the age-crime curve peaked earlier for property but not for violent offending, which Zhong ascribes to the continuity of Chinese 'culture' over the period.

Robert Wright (1994) asserts that the leading cause of violence is maleness, to which may be added youth and unmarried status (see Mesquida \& Wiener, 1996, 1999). In brief, violence is often about sexual selection. The classic psychological theory of violence is the frustration-aggression hypothesis, which holds that aggression is the response to the expected interference with a desired goal (Dollard et al., 1939, see also Berkowittz's 1989 reformulation). Stressing the primacy of sexual selection as the root of frustration is the distinctive contribution of evolutionary thinking. If that insight holds, there seem to be two strategies which fit into the primary prevention category, two distal, two proximal. The distal tactic concerns establishing sex ratios or sexual mores which do not deny sexual expression

${ }^{2}$ Paul Ekblom, shown the section in the text, comments Biological co-evolution of predator/prey capabilities etc is a simile, but cultural/ technical co-evolution of offending and preventing techniques is the real thing.

${ }^{3}$ http://www.smokecloak.co.uk/en/ accessed April 17 $7^{\text {th }} 2011$.

${ }^{4}$ http://news.bbc.co.uk/1/hi/uk/8642558.stm accessed April 13th 2011. 
among male adolescents and young adults. As Gottschall (2008) opines,

“...a real shortage of female reproductive capacity, relative to male demand, is endemic to the human condition. In this shortage lies the answer as to why men fight... sexual selection has shaped men to compete for women and for concrete material resources and for intangible social resources because... these resources [are] reliably converted to reproductive advantage" (pp. 48-49).

It is entirely unrealistic to suppose that sex ratios at birth should be manipulated in the interests of the prevention of later violent crime. Indeed, since the female population defines effective reproductive channel capacity, the population implications of such a strategy would be horrendous.

The second distal approach would involve an attempt to reduce anticipations of lifetime failure amongst adolescent males. Daly and Wilson (2005) note the higher rate of future discounting (in effect preferring short over long term rewards) among males and among the young (paradocically, given the increasing uncertainty of the future as one gets older). They note the greater variability of reproductive outcome among males, and the resulting competition amongst males. After justifying rate of homicide as a proxy for inter-male competition, they find homicide to be most frequent amongst those with least to lose, unemployed and unmarried men, with divorced and widowed men reverting to higher rates of homicide, Characterising the deployment of reproductive effort as a gamble, anticipation of the high probability of an early death or other form of removal from the reproductively active is consistent with the choice of a strategy of attempting risky and frequent impregnation. While plausibly argued, it is difficult to think of viable social policies which would substantially inflate the residual reproductive value of young men which would not be justified more powerfully by other egalitarian arguments.

The impracticality of both distal options makes the proximal ones more important.

The proximal tactics concern:

1) The nudgeability of human behaviour;

2) Harm reduction (here treated as a form of primary prevention), whereby the affordance or means for translating violent intent into injury or death are denied those likely to exhibit such intent,

These will be dealt with in turn.

Over the past 25 years or so there has been a gradually increasing recognition of the possibilities offered by focusing on crime events rather than on offenders (Gilling, 1997; Crawford, 1998).Overstating the case only slightly, the evidence for the success of intelligently conceived and well-implemented primary prevention (Clarke, 1992, 1997; Goldblatt \& Lewis, 1998; Sherman et al., 1998; Tilley, 2010) is very substantial. Such success is consistent with situational rather than dispositional theories in social psychology. The capacity of slight changes in setting to evoke substantial changes in behaviour represents a well-established tradition in social psychology, with Walter Mischel (1968) a pioneer. Mischel's analyses revealed that the individual's behavior, when closely examined, was highly dependent upon situational cues, rather than expressed consistently across diverse situations that differed in meaning. A neglected feature of Stanley Milgram's obedience studies was his manipulation of the proximity of the person apparently administering electric shocks and the person to whom they were ad- ministered, which yielded massive changes in the intensity of shocks they could be induced to administer (see Milgram, 1977). Momentous decisions (such as committing suicide) are remarkably changeable by removing one means of doing so, by making domestic gas supplies non-toxic (Clarke \& Mayhew, 1988), installing catalytic converters to vehicles (Lester \& Clarke, 1989), and restricting the size of paracetomol and aspirin packets (Hawton et al., 2001). More recently Zimbardo (2007) develops the point. Thaler and Ornstein (2008) rename the situational determinant the "nudge" and apply it widely to social policy. Human nudgeability, and the capacity to afford multiple uses for objects, it seems embarrassingly obvious to relate, is a consequence of the human evolutionary route, whereby a wide range of environments become habitable by dint of behavioural flexibility and innovation. The longstanding recognition of the fact of imitative learning, and the more recent exciting research and speculation about mirror neurons as the basis of such learning, including the imitation of prosocial behaviour (see Thomson 2010 for an introduction).

Turning to harm reduction, the concept of affordance provides one way of thinking about the situational specificity of behaviour alluded to earlier, and permits the elaboration of the concept of opportunity. The original Gibsonian (1950) meaning of affordance concerned things that you could actually do with objects. An object's affordance comprised what one could do with it. Don Norman (e.g. 1998) extended this to perceived affordance, ie actions that the thing suggested you do with them. Ekblom and Sidebottom (2007) describe it in the crime opportunity context as an offender's capacity to see utility in an object. While doing participant observation in an ex-prisoner's hostel, one of the writers observed a fight break out very quickly and a heavy glass ashtray was wielded as a weapon. To the writer, it had just been an ashtray a moment before! Baseball bats "afford" thoughts of violence more than cricket bats, and are sold in all large British sports stores, despite the fact that baseball is played very little in the UK. The position on glass as a weapon and on gun availability is more difficult to summarise. Conventional (annealed) drinking glasses or bottles, when broken, yield sharp edges capable of inflicting serious injuries. Such events are generally known as glassings. Toughened glass shatters on impact, and is relatively useless as a weapon. Yet a randomised controlled trial showed $60 \%$ more injuries from toughened glass than from annealed glass. The conclusion was reached that glass with lower impact resistance caused more injuries. "Toughened” glassware had lower impact resistance. Standards for toughening need to be developed. (Warburton \& Shepherd, 2000, see also Coomaraswamy \& Shepherd, 2003). Subsequent analysis showed that this counterintuitive result was a consequence of the greater resistance to breakage of annealed glasses, which occasioned the plea for revised standards for toughening (not developed at the time of writing). While the results were obviously disappointing, paradoxically they do illustrate that weapon characteristics were relevant to the degree of harm inflicted. For instance, assaults with bottles caused less severe injuries than assaults with drinking glasses. In a local initiative in Liverpool in 1997, a set of simple measures preventing glasses and bottles being taken onto the street reduced the rate of glassings by some $50 \%{ }^{5}$

\footnotetext{
${ }^{5}$ http://www.popcenter.org/library/awards/tilley/2001/01-49(W-cdrc).pdf
} accessed April $9^{\text {th }} 2011$. 
The media characterise Swiss gun crime as low, despite the wide availability of weapons by military reservists. However Killias (1993) found that Switzerland has five times as many homicides committed with guns as Great Britain versus only a slightly higher non-gun homicide rate. His explanation for the lack of gun use in other crime is that the military weapons that are kept in Swiss households are of little use to ordinary criminals, because they are heavy and far too long to be concealed under a coat or in a case. Zimring and Hawkins (1987) contend that the firearm effect consists in escalating consequences. They provide data on altercations involving knives far less often result in death, for example. Lott (2005) argues that the power-equalising effects of handguns is neglected in statistics. He uses national victimization survey to assert that women without a gun resisting attack are some four times greater than women resisting with a gun. The male difference is smaller but in the same direction. Grossman (2009) notes the relationship between remoteness of assailant to target enabled by modern weaponry and psychological ease of assault. He notes that changes in the realism of targets used during weapons training will affect rate of fire in battle. A historical nod in the direction of Konrad Lorenz is necessary. To him we owe the insight that animals with the most fearsome natural weapons are those with the best developed behavioural inhibitions on lethal assault. He wrote

“...all heavily-armed carnivores possess sufficiently reliable inhibitions which prevent the self-destruction of the species. ... No selection pressures arose in the prehistory of mankind to breed inhibitory mechanisms preventing the killing of conspecifics” (Lorenz, 1966, p. 233).

It is perhaps not too much of a stretch to say that the paucity of natural inhibitions on the expression of violence is consistent with the primary reduction focus on limiting the precipitating circumstances of violence and the weapons availability which set limits on the amount of harm done in violent attacks. Certainly some of the major examples of successful practice are of this type. These include place-oriented approaches to gun crime. Braga (2003) writes, with supporting research, that

"Officers can reduce gun crime by changing the features, facilities, and management of problem places. For example, if problem analysis reveals that easy access to common areas in front of a high school causes youth gun crimes to be clustered there immediately upon school release, police should experiment with ways to limit access to these areas during problem times. The practice of problem-oriented policing is still developing, and additional research is needed on different approaches to controlling gun violence hot spots". 6

Violence at pubs and bars is reduced (Scott \& Dedel, 2006) by maintaining:

"A comfortable and entertaining atmosphere reduces both frustration and boredom among patrons, which can reduce aggression levels. Lighting should not be so bright that it acts as an irritant, but also not so dim that it can conceal customers' activities. An important environmental consideration is the crowding level. Police in some jurisdictions enforce occupancy limits (primarily adopted for fire safety) as a means to control the bar crowding that can lead to fights. Redesigning a bar's interior to improve traffic flow and prevent congestion can

${ }^{6}$ http://www.popcenter.org/problems/gun_violence/summary/accessed April $9^{\text {th }} 2011$. reduce the opportunities for accidental bumps and drink spills that may escalate into fights". ${ }^{7}$

While such conclusions may seem self-evident, they do illustrate that manipulable aspects of the immediate environment can nudge behaviour from violence and/or reduce harm. Some sixty-four design guides on crime reduction, about a third addressing violence, have been published by the Centre for Problem-Oriented Policing (http://www.popcenter.org/) and are worth consulting to gain an impression of the range and types of problem in which demonstration projects have found place manipulation to be effective.

\section{Secondary Violent Crime Prevention}

It will be recalled that secondary prevention is oriented towards those who may be particularly prone to develop problematic behaviour. Aggressive behaviour appears very young and is characterized by high stability coefficients across many years (Olweus, 1979). Serbin and Karp (2003) reported that aggression (and depression) in primary school aged girls were predictive of aggression amongst their children. Of course the mechanisms may have no evolutionary relevance, but this does mean that there is reason for secondary intervention, particularly since aggression was linked with a variety of other unhappinesses in the lives of aggressors (Junget et al., 2007).

Many lines of research in evolutionary psychology have clear implications for secondary violence prevention. The two most obvious are selected for attention here. One is the evidence for apparent gene-specific effects of environment on the development of violent people. The second concerns the particular risks to children associated with step-parentage.

In her admirable, unfashionable classic The Nurture Assumption, Judith Rich Harris (1998) contends that the contributions which parents make to their children's development primarily comprise their genes and where they decide to set up home. She points out that in the socialization literature, the effects of parenting styles are confounded with those of shared genes. She reviews the literature on the relationship between parent characteristics and child characteristics and demonstrates that either the same characteristics must have different and largely unpredictable effects on children, or that those influences are largely illusory. Is poor parenting a risk factor in a child's development, or do parents tending to (for example) impulsivity, transmit that attribute through the conventional genetic means?

Familial inheritance is always both the result of genetic endowment and environment, but environments are made, and are often correlated with the dispositions of those who inhabit them. Moffitt and Caspi suggest with regard to antisocial behaviour;

"Environments are provoked by a person's genetically influenced behavior, or a person chooses environments consonant with her genotype, or a person's genotype results in him selectively finding himself in certain environments” (2006, p. 127)

The implications of Rich Harris's work are profound. They should be no surprise to those familiar with the earlier literature on criminality and biology (see, for example, Mednick \& Christiansen, 1977). The latter authors demonstrated that criminality in the biological parent is reflected in a higher prevalence ${ }^{7}$ http://www.popcenter.org/problems/assaultsinbars/accessed April $9^{\text {th }}$ 2011. 
of criminality in the child, whatever the criminal record status of the adoptive parent. More recent work under the flag of neurocriminology has looked in detail at brain functioning, conditioning and criminality (see for example Gao et al., 2010).

Some scholars suggest that searches for answers to questions such as these have led to a preoccupation with 'risk factors' that often confuse correlates with causes;

"Influential reviewers have concluded that the study of antisocial behaviour has been stuck in the 'risk-factor' stage (Farrington, 1988, 2003; Hinshaw, 2002; Rutter, 2003a, 2003b) because so few studies have used designs that are able to document causality (Rutter et al., 2001). A variable is called a 'risk factor' if it has a documented predictive relation with antisocial outcomes, whether or not the association is causal”. (Moffitt \& Caspi, 2006: p. 109).

Arguing whether behaviour is a result of biological characteristics or specific environmental experiences was likely the result of misdirection (Suomi, 2009). More exciting is the realization by many that both genetic (nature) and environmental (nurture) factors play crucial roles (e.g. Collins et al., 2000) and indeed both often interact to shape behaviour and its individual development (e.g. Rutter, 2001).

One illustration of the importance of understanding behaviour (including violence) from a gene $\mathrm{x}$ environment interaction perspective (hereafter, $G \times E$ ) is provided by studies with rhesus monkeys. It has been consistently shown that it those that have been reared by peers and not their biological mothers, appear much more "anxious in nature" and excessively "fearful” than their "mother-reared” counterparts' (Suomi, 1991, 1995). Indeed longitudinal studies have shown that male "peer-reared" monkeys consistently exhibit more extreme behaviours (and with increased frequency) such as being overly aggressive and overly impulsive, than those reared by biological mothers (Suomi, 1991, 2009).

So how can adopting evolutionary thought help explain such $\mathrm{G} \times \mathrm{E}$ interactions? Put briefly, we can surmise that those reared by peers and not their mothers, do not have their aggressive survival impulses attenuated. Indeed a predisposition to aggression and violence would be considered vital to survival in an environment where access to food and reproductive partners is hotly contested with rival male peers. With those fortunate to be raised by their mothers having their early nutritional and protection needs provided for in their formative years at least.

So should predictions of such behaviour by rhesus monkeys be based simply on an identification of early-rearing environments and not on gene $\times$ environment interactions?

The short answer is no as recent research points to such identifiable differences in behaviour between male "peer-reared" and "mother reared" monkeys as being more the result of gene $\times$ environment interaction rather than just early-rearing experience alone (Suomi, 2009).

The neurotransmitter serotonin is posited to be an important consideration when explaining unusual and extreme behaviour. More specifically, the occurrence of certain mental health problems, such as anxiety and depression, alongside behaviours such as fear, aggression and violence, has long been associated with decreased serotonergic functioning. The serotonin transporter gene (5-HTT) is generally held responsible for such a decrease in functioning when it occurs (Lesch et al., 1996), because it has 'a length variation in its promoter region that results in allelic variation in serotonin expression' (Suomi, 2009: p. 17). Heils et al. (1996) distinguish "long allele” (LL) from "short allele" (LS), with the latter raising the possibility of decreased serotonergic functioning and therefore, an increase in the likelihood of aggressive and violent behaviour.

Barr et al. (2003) found a "buffering effect" which appeared to mitigate some of the monkeys with the LS allele from the full effects of decreased serotonergic functioning, according to their early-rearing experience. Where high levels of aggression was observed in peer-reared monkeys with the LS allele, for mother-reared monkeys with the LS allele it was not, demonstrating an important interaction between genes and environment. Put simply, the consequences for these monkeys of having the notorious LS allele appear to differ dramatically according to whether the monkeys were raised by peers or whether they were buffered from its effects by being raised by their biological mothers. Suomi (2009) summarises the significance of this finding rather nicely;

Indeed, it could be argued on the basis of these findings that having the LS allele may well lead to psychopathology among monkeys with poor early rearing histories but might actually be adaptive for monkeys who develop secure early attachment relationship with their mothers' (p. 18).

In sum, compelling evidence is presented that genetic and early experience factors in interaction affect a monkey's capacity to regulate expression of fear and aggression (Suomi, 2009), with important implications for our own species;

"Clearly, the context in which development takes place matters a great deal for rhesus monkeys. It is hard to imagine how it could be less so for human development”. (Suomi, 2009: p. 19).

The importance of interactions is lent support by the work of Terrie Moffitt and her collaborators (see Moffitt, 1993, 1997, 2003) whose distinction of adolescent-limited and life-course persistent offenders casts the latter as predisposed as a result of inherited and/or early acquired neuropsychological deficit. Of particular current interest is the gene variant MOAO which lowers the activity of the enzyme monoamine oxidase A and which seems implicated in violence. This relationship is stronger amongst maltreated children (see Caspi et al., 2002). Of course, reflecting Rich Harris's insights, it is not necessarily the case that maltreatment activates the propensity to violence. Equally plausible is the notion that MOAO and other as yet to be identified violence-relevant genes drive both parental violence (in the form of maltreatment) and child aggression. In path terms, the message is simply that one ignores at one's peril genetic or other early factors disposing to preferences. KimCohen et al. (2006) conducted a replication and meta-analysis and concluded "These findings provide the strongest evidence to date that the MAOA gene influences vulnerability to environmental stress, and that this biological process can be initiated early in life” (p. 903). Widom and Brzustowicz (2006) found the effect in white children only, adding a further interactive complication.

The relevant research has not been slow to make its way into the courtroom. Bernet et al. (2007) describe their own experience and anticipate future developments as follows

"It seems possible that both the defence and the prosecution may be interested in introducing evidence regarding a defendant's life experiences and genetic make-up to a jury. In a case of aggravated assault, for instance, the prosecution may say that 
a defendant has violent tendencies (based on the person's genotype conveying low MAOA activity and a history of severe child mistreatment) and should be removed from society for as long as possible. On the other hand, the defence may say during the sentencing phase of a first-degree murder case that a person's genotype and history of severe abuse during childhood is mitigating” (p. 8).

It is telling that the work of the Moffitt-Caspi team and its replication has been applied to the court literature before the child protection literature (as far as the writers have been able to determine after questioning relevant domain experts). What are the implications for child protection? We may discard the notion of being indifferent to the parental practices of those children whose genotypes afford them some protection against the acquisition of violent personalities! Rather it places an extra premium on ensuring as far as possible the quality of child care generally. Not to do so is effectively to collude in allowing preventable harm which compounds the effects of the genetic lottery itself. A parallel may perhaps be drawn with phenylketonuria (PKU), where screening on neonates allows management, and avoidance of the progressive mental impairment which otherwise ensues.

A brief aside can perhaps be permitted. It has been speculated that the mechanism underlying the MAOA-abuse interaction may be epigenetic in nature. Kramer (2005) defines epigenetics as "the study of stable alterations in gene expression by nongenetic mechanisms resulting in stable alterations in phenotype” (p. 16). In an astonishingly prescient article, Kendler and Eaves (1986) anticipate the essential facts of epigenetics, focusing on sensitivity to the environment. This, both in the sense of responsivity to the cues which make primary crime reduction effective, and in the particular sense of empathy (or its lack, see Baron-Cohen, 2011) will be a crucial point of departure for research which seeks to link applied criminology and evolution.

Speculatively, epigenesis makes evolutionary sense in a wide number of cognitive and affective contexts. This form of gene regulation is primarily under matrilineal control and has evolved partly to co-ordinate in-utero development with maternal resource availability (Keverne \& Curley, 2008). A detailed general introduction to epigenetics is to be found in Allis, Jenuwein and Reinberg (2007). Szyf et al. (2009) provide a clear brief account of the methylation and other events underpinning epigenesis, and report research on putative epigenetic effects on maternal care, and preliminary work on epigenesis and lifetime trajectories of aggressive behaviour.

In respect of violence, epigenetic effects which favour agonistic behaviour only in environments in which parents had exhibited similar behaviour towards them, makes intuitive sense, and its neglect culpable. Kramer (2005) contends

“...the future of child and adolescent psychiatry is ethically connected to the developmental processes designed by natural selection and inherited by way of evolution. For anything resembling the continuation of normal human interactions and normal family-centred developmental processes, our work should be inter-woven with the complex interactions occurring between the epigenome and the phenotype” (p. 297).

The same could certainly be said of criminology. The defensible next step will be to reanalyze longitudinal studies of criminality (the Cambridge study now incorporates data from three generations) to test epigenetic hypotheses.

\section{Preventing Child Homicide?}

For most people, the killing of a child is felt to be the most heinous and distressing of all crimes (Adler \& Polk, 2001). It is mercifully rarer for children to be victims of homicide than adults. In England and Wales there will be approximately 110 child homicides per year from an average total number of approximately 700 recorded homicides, roughly equating to $14 \%$ of all homicide victims (Brookman, 2005). Quite understandably, child homicide provokes the most outrage from the public (Adler \& Polk, 2001). As a category of crime it has also been identified as an important influence on public confidence in law enforcement (Innes, 2003)

Gene-centred evolution-based speculation (as no doubt elaborated elsewhere in this issue) would suggest that kinship would reduce child killings, and those in a parenting role without a kin relationship would be more induced to kill, This should be particularly true of de facto "fathers" since effort spent nurtuting someone else's children would retract from available future reproductive attention. Daly and Wilson (1988) in a ground-breaking study of child homicides in the US concluded that children were approximately 100 times more likely to be killed by a "non-biological parent" (e.g. step-parent, cohabitee or boyfriend/girlfriend of a biological parent) than a biological one. Similar findings have since been found in other parts of the world including Canada (Daly \& Wilson, 1998) and Australia (Adler \& Polk, 2001). In Canada, Daly and Wilson (1988, 1998) found a co-residing step-parent was approximately seventy times more likely to kill a child under two years of age than a co-residing genetic parent.

Creighton (1989), in a report produced for the children's charity the NSPCC (the National Society for the Prevention of Cruelty to Children), found that in England and Wales for the period 1983-1987 almost a third of those recorded as victims of intentionally inflicted physical injuries lived with one "natural" (biological) and one "substitute" (non-biological) parent. A random sample of children within the same age-range from the wider population of England and Wales would have comprised only three percent (Daly \& Wilson, 1998).

In support of Daly and Wilson's $(1988,1998)$ finding that young children are disproportionately at risk of homicide by step-parental males (more than 100 times more so). Adler and Polk (2001) in their Australian study of child homicide also identify that when young children are killed it is often by their mother's de facto partner (i.e. a young step-father figure) rather than at the hand of their biological fathers. Further support is provided by a recent more localized study of 127 child homicides carried out by the first author (Roach \& Shepherd, 2010) where in the case of young child victims the mother's de facto partner (i.e. the child's non-biological father) was most commonly charged with their murder. British readers will be reminded of the tragic case of "Baby P", where seventeen month old Peter Connolly was killed by his mother, her de facto partner (and his brother) after months of sustained physical and emotional abuse. ${ }^{8}$

\footnotetext{
${ }^{8}$ http://media.education.gov.uk/assets/files/pdf/s/second\%20serious\%20case \%20overview\%20report\%20relating\%20to\%20peter\%20connelly\%20dated \%20march\%202009.pdf (accessed 14/04/2011).
} 
Research has uniformly shown that it is more common for older children to be killed by their biological fathers than by male step-parental figures. (Daly \& Wilson, 1988, 1998; Adler \& Polk, 2001) A common scenario is where the father attempts filicide-suicide, as response to a marriage break-up, separation from his children, or as an act of revenge against the mother (Adler \& Polk, 2001). Mothers who kill older children appear generally to do so "to save" them from a perceived life of misery, often by successful filicide-suicide. For mothers, revenge does not appear to be a motivating factor in the killing of their children. Love does (Adler \& Polk, 2001).

Mothers who kill their children appear to overwhelmingly do so within the child's first year of life (neonaticide-within the first 24 hours being most common see Adler \& Polk, 2001) Psychiatric illness is often deemed a mitigating circumstance (Adler \& Polk, 2001; Roach \& Shepherd, 2010).

Traditional criminological explanations struggle to explain why, for example, young children are often more vulnerable to becoming victims of homicide at the hands of a step-parental figure than by a biological parent. Often quoted explanations for crime per se, such as deprivation and poor educational attainment, do not adequately explain, for example, why it is that step-parental figures from all social strata and educational backgrounds are consistently over-represented as perpetrators of child homicide. Indeed the problem of explaining why takes us back to the old problem of confusing correlates and causes. As we have endeavoured to show here in this short article, applying evolutionary thinking fares much better.

Although our desire for British criminologists to incorporate evolutionary thinking into the current understandings and explanations for crime, we must not lose sight of our purpose with this article of preventing violence. Theoretical understanding may be one thing but practical application is another. What we find most worrying is that the illuminating research on child homicide discussed has not made its way to practitioners working in child protection arenas in the UK.

From discussions with child social work colleagues, the authors are quite convinced that neither the work of Daly and Wilson, Adler and Polk, or any other like-minded research of child homicide (enlightened by evolutionary thinking) has made its way to those in the UK charged with the Hercuean task of working in child protection. Our initial soundings suggest that this most enlightening research on child homicide has not been translated into prevention practice. The reason may be its origin, grounded in evolutionary thought dismissed out of hand. It may also be that there is a trade-off between child protection and the stigmatization of step-parents As for the first possible reason, miscomprehensions and misgivings about genes and behavior have probably prevented the dissemination and adoption of such vital knowledge being put into practice by those working in child protection. If this proves to be the case then the most significant child homicide prevention measure we can propose is that those working in child protection, such a social workers and health visitors, be educated about this research and thinking as part of their training, and that the associated guides and literature incorporate it as a matter of urgency. Our plea to wider criminology, and most importantly to those practitioners charged with protecting children, is therefore, the same. In order to understand and prevent violence evolutionary thinking needs to be embraced.

\section{Violence against Women}

According to the 2009/10 British Crime Survey (BCS) seven per cent of women aged between 16 and 59 years in England and Wales were victims of domestic abuse, compared with four per cent of men (Hall \& Innes, 2011). The majority of the violence was described as "non-sexual" abuse by a partner. Although only fourteen per cent of the total 2,087,000 violent incidents estimated by the BCS for that year were described as domestic violence, those that collected the data are careful to add a caveat proclaiming that equivalent figures have been found to be up to five times higher where participant "selfcompletion" had been used instead of the BCS "face-to-face" method (Hall \& Innes, 2011).

Our point is that it is the consensus that the prevalence and frequency of domestic violence are far greater than recorded crime statistics or the BCS suggest. Domestic violence is ubiquitous and as such if we are working to prevent violence than we can best make inroads by focussing on intimate partner violence. For example, a study in England and Wales (19952000) showed that 30 per cent of all the homicides were 'femicides'. Moreover, 57 per cent of these female victims were killed by an intimate (or ex-intimate) male sexual partner (Brookman, 2005).

How can an evolutionary informed violence prevention strategy help reduce domestic violence? The first step, as always, should be to try and understand what is going on. Let's start with why men might go to war?

Tooby and Cosmides provide an exquisite evolutionary psychology of warfare where they identify four essential conditions that must be met for adaptations to evolve that allow for initiating such coalitional aggression as war. They call these conditions "the risk contract of war"-we draw the reader to their first condition: The average long-term gain in reproductive resources must be sufficiently large to outweigh the reproductive costs of engaging in warfare over evolutionary time. (Tooby \& Cosmides, 1990)

The most likely candidate is an increase in copulations as men have a great deal to gain if the result of engaging in war results in substantial increase in reproductive access to women. As Buss phrases it,

"Although few wars are initiated solely with the stated intent of capturing women, gaining more copulations is almost always viewed as a desired benefit of successfully vanquishing an enemy” (2004: p. 298).

The work of Chagnon in his study of the warfare between the Yanomamö villager tribes lends support to this argument, where it was found to be nearly always linked to reproductive access to women (see Chagnon, 1983 for a very interesting anthropological study). We cannot resign the use of violence by men to secure female reproductive access to "less developed" societies. The mass rape of females by the victors has been an established part of warfare throughout history, with for example, the Norman invasion of 1066, in the first and second world wars, and in the civil war in the former Yugoslavia. It might not be the primary motivating factor for men going to war but securing access to women is certainly part of the promise of reward. The point being made, as it has been throughout this publication, is that males (especially young ones) will do whatever it takes to access females, regardless of the risks in- 
volved.

Male "sexual jealousy" is the most frequently given explanation for intimate partner violence (Dobash \& Dobash, 1979; Daly \& Wilson, 1988; Buss, 2000, 2005; Goetz et al., 2008) and so will only be briefly mentioned here. For example, Polk refers to male on female violence as being primarily motivated by "jealousy/control" on the part of the male (1994: p. 18). Put simply, men appear to use violence against women as a tactic to restrict their sexual behaviour. Primarily as means of enforcing sexual (i.e. reproductive) "exclusivity” (Daly \& Wilson, 1988; Wilson \& Daly, 1996; Buss \& Malamuth, 1996). For example, Fiona Brookman found that more than 80 per cent of femicides occurred where the female was either planning to leave her partner, or where he perceived her at least to have been "unfaithful" with another sexual intimate, thereby compromising sexual exclusivity (Brookman, 2000). Some suggest that violence against women is best understood as being "a behavioural output of male sexual jealousy” (Goetz et al., 2008: p. 67). Occasionally, that violence is lethal resulting in female homicide (Daly \& Wilson, 1988; Polk, 1994).

The foremost writer on this topic from an evolutionary perspective is Anne Campbell. Campbell makes the observation that in trying to explain the gender difference in crime the male-centered approach has dominated evolutionary psychology, where there appears to be a broad consensus that the motivation to achieve status and 'surplus resources' is more critical to male than female reproductive success (Campbell, 2002, 2009). However, where a female-centered approach is instead taken a different perspective on male on female violence is achieved;

"Her most important proximal goal is to stay alive because it is she who, given 100 per cent maternal certainty, limited reproductive years and high replacement costs, has most to gain by ensuring that her offspring survive” (Campbell, 2009: p. 124).

Reproduction (and therefore, by virtue, sexual intercourse), poses more of a risk to female safety and survival than for males (Campbell, 2009). Lew and colleagues rather eloquently describes this as a male-female genetic arms race in which females must evolve defences against the lethal potential of the sex drive of males (Lew et al., 2006).Intimate partner violence being one such defence as when women kill it is more often than not an intimate (or previously intimate) partner that is the victim (Daly \& Wilson, 1988).

So very briefly how can evolutionary thinking contribute to preventing domestic violence against women?

The most obvious answer is that women who experience domestic violence should be encouraged not only to report it as soon as possible, but they must also be able to access immediate help, in order that they and their children "stay alive". Research has consistently shown that a significant number of female victims of domestic homicide have experienced domestic violence previously (Wallace, 1986; Campbell, 1992; Smith et al., 1998). Lethal domestic violence against women being often the final tragedy in a long-running sequence of violent and emotional attacks by an intimate (or ex) partners. Mercifully, in the UK campaigns encouraging women to report domestic violence have been frequent and with some degree of success, hopefully exemplified by the year on year increase in recorded domestic violence incidents. Spousal homicide reflecting an extreme manifestation of the same basic conflicts that inspire sub-lethal marital violence on a much larger scale (Daly \& Wilson, 1988; Brookman, 2005).

The important finding domestic violence is generally perpetrated by males against female sexual intimates planning to leave them is also crucial with regards preventing violence against women. Research showing that a substantial proportion of femicides are connected to separation (or the threat of) support strongly the idea of male sexual proprietariness and the need for males to control female reproduction (Daly \& Wilson, 1988).

We may not be able to predict on an individual basis whether domestic violence is likely to occur in specific households, but evolutionary thinking has highlighted when it is most likely to occur and who is the likely perpetrator. Such knowledge must be used to prevent the escalation to lethal violence by, for example, making it easier and more practical for women to leave their violent partners without fear of reprisal, as we know planning to leave is common flash-point in violence by men against women. We give Daly and Wilson a deserved last word;

"Killing is just the tip of the iceberg: For every murdered wife, hundreds are beaten, coerced and intimidated. Although homicide probably does not often serve the interests of the perpetrator, it is far from clear that the same can be said of sub-lethal violence” (1988, p. 205).

\section{From Just So Stories to Evidence-Based Crime Reduction}

Perhaps the first task is education of the next generation of criminologists. This is no small order given the accumulated hostility, sociological and religious and the complexity of modern evolutionary biology, whose mastery is a necessary condition of defensible contributions on violence prevention made by criminologists. Some are tentatively introducing Darwinian thinking into their books (see for example Wortley, 2011) but they are rare, and the present writers stress their own inadequacies in treating with evolutionary biology writings. The Catch 22 is that the points of possible connection have to be simple enough to be comprehensible to a skeptical audience, which makes them vulnerable to accusations of superficiality and the Just So criticism. So what is presented below is a set of possibilities ranked from those which many criminologists may perhaps be prepared to consider to those which are currently regarded as difficult and alien.

A further complication is that those measures which have most often proven effective in violence and harm reduction are situational in character, and hence are best addressed in the more sophisticated outcrops of Darwinian thinking. Laland and Brown (2002) distinguished four major contemporary approaches; human behavioural ecology, evolutionary psychology, memetics, and gene-culture co-evolution. The latter two adopt the meme concept, i.e. the unit for carrying cultural ideas, symbols, or practices, which can be transmitted from one mind to another, cultural analogues to genes, in that they self-replicate, mutate, and respond to selective pressures. Changes in crime tactic memes co-evolving with thresholds of inclination to aggress will certainly be necessary for short and middle-term variation in manifestations of violence.

Returning to a desensitization process for criminologists, three stages may be envisaged.

Defense mechanism analogies. Just as the products Smoke 
Cloak and Smoke Bandit simulate the defence tactic of the squid, and the panic alarm can be regarded as equivalent to alarm calls, are there other analogues? Is defecation an effective last ditch tactic to avoid rape? Are there diversionary tactics to avoid attack on one's family equivalent to birds feigning injury to divert predators from the nest? In what circumstances are mimicking less vulnerable species (as the hoverfly the wasp) relevant in avoiding violence (see Felson, 2006 for some suggestions), Interesting criminologists in such questions may invite derision from evolutionary biologists, but may be a useful hook for criminological interest, and can be presented purely as what they are, namely no more than analogies.

Bootstrapping on current interests. Places differ in their proneness to crime, including violent crime. One key variable appears to be the permeability of residential areas. Cul-de-sacs (particularly sinuous cul-de-sacs) are massively less prone to victimization (Johnson \& Bowers, 2010). Intuitively this is because people enter such roads because they live there or to visit. The have a reason they can express or defend. In evolutionary psychology, Dunbar's number. Robin Dunbar (1992) surveyed village and tribe sizes and settled on 150 as the estimated size of a neolithic farming village; 150 as the splitting point of Hutterite settlements; 200 as the upper bound on the number of academics in a discipline's sub-specialization; 150 as the basic unit size of professional armies in Roman antiquity and in modern times since the 16th century; and notions of appropriate company size. In short, he concluded that 150 was the neocortex-limited community size. Dunbar thinking could be applied to people recognition patterns by street network and layout to determine how they linked to patterns of assault and other victimization. The second writer was unfortunate to be present at a meeting of geographers and social scientists at a prestigious university at which the Dunbar number was introduced, to ill-deserved derisive laughter.

A second possible avenue of infiltration is surely due for the trialing of child protection work on kin selection principles and Daly and Wilson research.

Getting serious, this would consist of agent-based modeling of gene-meme coevolution models to assess fit to distributions of violence by time, place and person (see Cavalli-Sforza \& Feldman, 1981) for background. Such an approach would revolutionise criminal career understanding and preventive sentencing-but that would require persuading judges about evolutionary understanding of crime. That is perhaps a bridge too far to contemplate now.

\section{References}

Adler, C., \& Polk, K. (2001). Child victims of homicide. Cambridge: Cambridge University Press.

Allis, C. D., Jenuwein, T., \& Reinberg, D. (2007). Epigenetics. New York, NY: Cold Spring Harbour Laboratory Press.

Baron-Cohen, S. (2011). Zero degrees of empathy. London: Allen Lane.

Barr, C. S., Newman, T. K., Becker, M. L., Parker, C. C., Champoux, M., Lesch, K. P., et al. (2003). The utility of the non-human primate model for studying gene by environmental interactions in behavioural research. Genes, Brain, and Behaviour, 2, 336-340.

doi:10.1046/j.1601-1848.2003.00051.x

Bernet, W., Vnencak-Jones, C., Farahany, N., \& Montgomery, S. A. (2007). Bad nature, bad nurture and testimony regarding MAOA and SLC6A4 genotyping at murder trials. Journal of Forensic Psychiatry and Psychology, 52, 1-9.
Berkowitz, L. (1989). Frustration-aggression hypothesis: Examination and reformulation. Psychological Bulletin, 106, 59-73.

doi:10.1037/0033-2909.106.1.59

Brantingham, P. J., \& Faust, F. L. (1976). A conceptual model of crime prevention. Crime and Delinquency, 22, 130-146. doi:10.1177/001112877602200302

Brookman, F. (2000). Dying for control: Men, murder and sub-lethal violence in England and Wales. British Criminology Conference Proceedings, 3. URL (last checked 23 June 2010). http://www.lboro.ac.uk/departments/ss/bsc/bccsp/vol03/brookman.ht $\mathrm{ml}$

Brookman, F. (2005). Understanding homicide. London: Sage Publications Limited.

Buss, D. M., \& Shackelford, T. K. (1997). Human aggression in evolutionary psychological perspective. Clinical Psychology Review, 17, 605-619. doi:10.1016/S0272-7358(97)00037-8

Buss, D. M. (2000). The dangerous passion. New York, NY: Free Press.

Buss, D. M. (2004). Evolutionary psychology: The new science of the mind (2nd ed.). Boston: Pearson.

Buss, D. M. (2005). The murderer next door. New York, NY: Penguin Press.

Buss, D. M., \& Malamuth, N. M. (1996). Sex, power, conflict. New York, NY: Oxford University Press.

Campbell, A. (2002). A mind of her own: The evolutionary psychology of women. Oxford: Oxford University Press. doi:10.1093/acprof:oso/9780198504986.001.0001

Campbell, A. (2009). Gender and crime. In A. Walsh and K. M. Beaver (Eds.), Biosocial criminology: New directions in theory and research. New York, NY: Routledge.

Campbell, J. (1992). If I can't have you, no one can: Power and control in homicide of female partners. In J. Radford and D. E. H. Russell (Eds.), Femicide: The politics of woman killing. Buckingham: Open University Press.

Caspi, A., McClay, J., Moffitt, T. E., Mill, J., Martin, J., Craig, I., Taylor, A., \& Poulton, R. (2002). Evidence that the cycle of violence in maltreated children depends on genotype. Science, 297, 851-854. doi:10.1126/science.1072290

Cavalli-Sforxa, L. J., \& Feldman, M. W. (1981). Cultural transmission and evolution: A quantitative approach. Princeton, NJ: Princeton University Press.

Chagnon, N. A. (1983). Yanamamö: The fierce people (3rd ed.). New York, NY: Holt, Rinehart and Winston.

Clarke, R. V. (1992). Situational crime prevention: Successful case studies. New York, NY: Harrow \& Heston.

Clarke, R. V. (1997) Situational crime prevention: Successful case studies. (2nd ed.). New York, NY: Harrow \& Heston.

Clarje R. V., \& Mayhew, P. (1988). The British gas suicide story and its criminological implications. Crime and Justice, 10, 79-116. doi:10.1086/449144

Cohen, L. E., \& Felson, M. (1979). Social change and crime rate trends. American Sociological Review, 44, 588-608. doi:10.2307/2094589

Collins, W. A., Maccoby, E. E., Steinburg, L., Hetherington, E. M., \& Bornstein, M. H. (2000). Contemporary research on parenting: The case for nature and nurture. American Psychologist, 55, 218-232. doi:10.1037/0003-066X.55.2.218

Coomaraswamy, K. S., \& Shepherd, J. P. (2003). Predictors and severity of injury in assaults with barglasses and bottles. Injury prevention, 9, 81-84. doi:10.1136/ip.9.1.81

Coyne, J. A. (2009). Why evolution is true. Oxford: Oxford University Press

Crawford, A. (1998). Crime prevention and community safety: Politics, policies and practices. Harlow: Longman

Creighton, S.J. (1989). Child Abuse Trends in England and Wales 1983-1987. London: NSPCC.

Daly, M., \& Wilson, M. (1988). Homicide. Hawthorne, CA: Aldine de Gruyter.

Daly, M., \& Wilson, M. (1998). The truth about Cinderella: A Darwinian view of parental love. London: Orion Publishing. 
Dobash, R. E., \& Dobash, R. P. (1979). Violence against wives. New York, NY: Free Press.

Dollard, J., Doob, L., Miller, N., Mowrer, O., \& Sears, R. (1939). Frustration and aggression. New Haven, CT: Yale University Press. doi:10.1037/10022-000

Dunbar, R. I. M. (1992). Neocortex size as a constraint on group size in primates. Journal of Human Evolution, 22, 469-493. doi:10.1016/0047-2484(92)90081-J

Ekblom, P. (1997). Gearing up against crime: A dynamic framework to help designers keep up with the adaptive criminal in a changing world. International Journal of Risk, Security and Crime Prevention, 2, 249-265.

Ekblom, P. (1999). Can we make crime prevention adaptive by learning from other evolutionary struggles? Studies on Crime and Crime Prevention, 8, 27-51.

Ekblom, P., \& Sidebottom, A. (2007). What do you mean, "Is it secure?" Redesigning language to be fit for the task of assessing the security of domestic and personal electronic goods. European Journal on Criminal Policy and Research, 14, 61-87. doi:10.1007/s10610-007-9041-8

Farrington, D. P. (1988). Studying changes within individuals: The causes of offending. In M. Rutter (Ed.), Studies of psychosocial risk: The power of longitudinal data. Cambridge: Cambridge University Press.

Farrington, D. P. (2003). Developmental and life-course criminology. Criminology, 41, 201-235. doi:10.1111/j.1745-9125.2003.tb00987.x

Felson, M. (1994). Crime and everyday life (1st ed.). Thousand Oaks, CA: Pine Forge Press.

Felson, M. (2002). Crime and everyday life (3rd ed.). London: Pine Forge.

Felson, M. (2006). Crime and nature. London: Sage.

Foley, D., Eaves, L., Wormley, B, Silberg, J., Maes, H., Hewitt, J., Kuhn, J., \& Riley, B. (2004). Childhood adversity, MAOA genotype, and risk for conduct disorder. Archives of General Psychiatry, 61, 738-744. doi:10.1001/archpsyc.61.7.738

Gao, Y., Raine, A., Venables, P. H., Dawson, M. E., \& Mednick, S. A. (2010). Association of poor childhood fear conditioning and adult crime. American Journal of Psychiatry, 167, 156-160. doi:10.1176/appi.ajp.2009.09040499

Goetz, A. T., Shackelford, T. K., Starratt, V. G., \& Mckibbin, W. F. (2008). Intimate partner violence. In J. D.Duntley and T. K. Shackelford (Eds.), Evolutionary forensic psychology: Darwinian foundations of crime and law. New York, NY: Oxford University Press.

Gibson, J. J. (1950). The perception of the visual world. Boston, MA: Houghton Mifflin.

Hall, P., \& Innes, J. (2011). Violent and sexual crime. In J. Flatley, C. Kershaw, K. Smith, R. Chaplin and D Moon, (Eds.), Crime in England and Wales 2009/10: Findings from the British Crime Survey and police recorded crime (3rd ed.). London: Home office.

Holmes, R. (2009). The age of wonder. London: Harper.

Gilling, D. (1997). Crime prevention. London: Routledge

Goldblatt, P., \& Lewis, C. (Eds) (1998). Reducing offending: An assessment of research evidence on ways of dealing with offending behaviour. Home Office Research Study, 187. London: HMSO.

Gottfredson, M., \& Hirschi, T. (1990). A general theory of crime. Stanford: Stanford University Press.

Gottschall, J. (2008). The rape of troy. Cambridge: Cambridge University Press.

Grossman, D. (2009). On killing (rev ed.) New York: Little Brown.

Hawton, K., Townsend, E., Deeks, J., Appleby, L., Gunnell, D., Bennewith, O., \& Cooper, J. (2001). Effects of legislation restricting pack sizes of paracetomol and salicylate on self-poisoning in the United Kingdom: Before and after study. British Medical Journal, 322, 1-7. doi:10.1136/bmj.322.7296.1203

Heils, A., Teufel, A., Petri, S., Stober, G., Riederer, P., Bengel, B., \& Lesch, K. P. (1996). Allelic variation of human serotonin transporter gene expression. Journal of Neurochemistry, 6, 2621-2624.

Hinshaw, S. P. (2002). Intervention research, theoretical mechanisms, and causal processes related to externalizing behavior patterns. Development and Psychopathology, 14, 789-818.

doi:10.1017/S0954579402004078

Hirschi, T., \& Gottfredson, M. (1983). Age and the explanation of crime. American Journal of Sociology, 89, 552-584. doi:10.1086/227905

Innes, M. R. (2003). Investigating murder: Detective work and the police response to criminal homicide. Oxford: Oxford University Press.

Johnson, S., \& Bowers, K. J. (2010). Permeability and burglary risk: Are cul-de-sacs safer? Quantitative Journal of Criminology, 26, 89-111. doi:10.1007/s10940-009-9084-8

Johnson, S. D., Summers, L., \& Pease, K. (2009). Offender as forager? A direct test of the boost account of victimisation. Journal of Quantitative Criminology, 25, 181-200. doi:10.1007/s10940-008-9060-8

Jones, O. D. (2005). Evolutionary psychology and the law. In D. M. Buss (Ed.), The handbook of evolutionary psychology. New York, NY: Wiley

Junger, M., Feder, L., \& Cote, S. M. (2007). Policy implications of present knowledge on the development and prevention of physical aggression. European Journal on Criminal Policy and Research, 13, 301-326. doi:10.1007/s10610-007-9052-5

Kendler, K. S., and Eaves, L. J. (1986). Models for the joint effect of genotype and environment on liability to psychiatric illness. American Journal of Psychiatry, 143, 273-297.

Keverne, E. B., \& Curley, J. P. (2008). Epigenetics, brain evolution and behaviour. Frontiers in Neuroendocrinology, 29, 398-412. doi:10.1016/j.yfrne.2008.03.001

Killias, M. (1993). International correlations between gun ownership and rates of homicide and suicide. Canadian Medical Association Journal, 148, 1721-1725.

Kim-Cohen, L., Caspi, A., Taylor, A., Williams, B., Newcombe, R., Craig, I. W., \& Moffitt, T..E. (2006). MAOA, maltreatment, and gene-environment interaction predicting children's mental health: New evidence and a meta-analysis. Molecular Psychiatry, 11, 903-913. doi:10.1038/sj.mp.4001851

Kramer, D. A. (2005). Nature, nurture and epigenetics. American Association of Child and Adolescent Psychiatry News, 24, 294-297.

Krug, E.G. et al. (2002). World report on violence and health. Geneva: WHO.

Lesch, K. P., Bengel, D., Heils, A., Sabol, S. Z., Greebderg, B. D., Petri, S. et al. (1996). Association of anxiety-related traits with a polymorphism in the serotonin transporter gene regulatory region. Science, 274, 1527-1531. doi:10.1126/science.274.5292.1527

Lester, D., \& Clarke, R. V. (1989). Effects of the reduced toxicity of car exhaust on accidental deaths: A comparison of the United States and Great Britain. Accident Analysis \& Prevention, 21, 191-196. doi:10.1016/0001-4575(89)90086-9

Lew, T. A., Morrow, E. H., \& Rice, W. R. (2006). Standing genetic variance for female resistance to harm from males and its relationship to intralocus sexual conflict. Evolution, 60, 97-105.

Loader, I., \& Sparks, R. (2010). Public criminology. London: Routledge.

Lorenz, K. (1966). On aggression. London: Methuen.

Lott, J. R. (2006). More guns, less crime (3rd ed.). Chicago, IL: University of Chicago Press.

Maguire, M., \& Brookman, F. (2005). Violent and sexual crime. In N. Tilley (Ed.) Handbook of crime prevention and community safety. Cullompton: Willan.

Mednick, S. A., \& Christiansen, K. O. (1977). Biosocial bases of criminal behaviour. New York, NY: Gardner Press.

Mesquida, C., \& Wiener, N. (1996). Human collective aggression: A behavioural ecology perspective. Ethology and sociobiology, 17, 247-262. doi:10.1016/0162-3095(96)00035-0

Mesquida, C., \& Wiener, N. (1999). Male age composition and severity of conflicts. Politics and the life sciences, 18, 181-189.

Milgram, S. (1977, 2010). The individual in a social world: Essays and experiments (3rd ed.). New York, NY: Pinter and Martin

Mischel, W. (1968). Personality and assessment. New York, NY: 
Wiley.

Moffitt, T. E. (1993). Adolescence-limited and life-course-persistent antisocial-behavior a developmental taxonomy, Psychological Review, 100, 674-701. doi:10.1037/0033-295X.100.4.674

Moffitt, T. E. (1997). Adolescent-limited and life-course persistent offending: A complementary pair of developmental theories. In T. Thornberry (Ed.), Developmental theories of crime and delinquency. Advances in criminological theory. New Brunswick, NJ: Transaction Books.

Moffitt, T. E. (2003). Life-course-persistent and adolescent-limited antisocial behavior. In B. B. Lahey et al. (Eds.), Causes of conduct disorder and juvenile delinquency. New York, NY: Guilford Press.

Moffitt, T. E., \& Caspi, A. (2006). Evidence from behavioural genetics for environmental contributions to antisocial conduct. In P. O. H. Wikström and R. J. Sampson (Eds.), The explanation of crime: Context mechanisms and development. Cambridge: Cambridge University Press.

Norman, D. (1998). The design of everyday things. Boston, MA: MIT Press.

Nowak, M. (2011). Super cooperators. London: Canongate.

Olweus, D. (1979). Stability of aggressive reaction patterns in males: A review. Psychological Bulletin, 86, 852-875. doi:10.1037/0033-2909.86.4.852

Pease, K. (2005). Science in the service of crime reduction. In N. Tilley (Ed.), Handbook of crime prevention and community safety. Cullompton: Willan.

Pease, K. (2010). Crime Science. In S. Shoham (Ed.) International handbook of penology and criminal justice. London: Taylor and Francis.

Polk, K. (1994). When men kill: Scenarios of masculine violence. Cambridge: Cambridge University Press.

Rich, H. J. (1998). The nurture assumption. London: Bloomsbury.

Roach, J., \& Pease, K. (in press). Evolution and crime. Cullompton: Willan

Roach, J., \& Shepherd, A. (2010). Thirty years of homicide in West Yorkshire 1979-2009. A Report Commissioned by the Homicide and Major Enquiry Team, West Yorkshire Police. Huddersfield: University of Huddersfield.

Rutter, M. (2001). How can we know environment really matters? In F. Lamb-Parker, J. Hagen and R. Robinson (Eds.), Developmental and contextual transition of children and families: Implications for research, policy, and practice. New York, NY: Columbia University Press.

Rutter, M., Pickles, A., Murray, R., \& Eaves, L. (2001). Testing hypotheses on specific environmental causal effects on behavior. Psychological Bulletin, 127, 291-324 doi:10.1037/0033-2909.127.3.291

Rutter, M., (2003a). Commentary: Causal processes leading to antisocial behavior. Developmental Psychology, 39, 372-378. doi:10.1037/0012-1649.39.2.372

Rutter, M. (2003b). Crucial paths from risk indicator to causal mechanism. In B. Lahey, T. E. Moffitt and A. Caspi (Eds.), The causes of conduct disorder and serious juvenile delinquency. New York, NY: Guilford Press.

Serbin, L. A., \& Karp, J. (2003). Intergenerational studies of parenting and the transfer of risk from parent to child. Current Directions in Psychological Science, 12, 138-142. doi:10.1111/1467-8721.01249

Sherman, L. W, Gottfredson, D., Mackenzie, D., Eck, J., Reuter, P., \& Bushway, S. (1998). Preventing crime: What works, what doesn't, what's promising. Washington, DC: National Institute of Justice.

Smith, B., \& Stevens, R. (2002). Evolutionary psychology. In D. Miell, A. Phoenix and K. Thomas, (Eds.), Mapping Psychology, 1, Milton
Keynes: Open University Press.

Smith, P. H., Moracco, K., \& Butts, J. (1998). Partner homicide in context: A population-based perspective. Homicide Studies, 2/4, 400-421. doi:10.1177/1088767998002004004

Suomi, S. J. (1991). Up-tight and laid-back monkeys: Individual differences in the response to social challenges. In S. Brauth, W. Hall and R. Dooling (Eds.), Plasticity of development. Cambridge, MA: MIT Press

Suomi, S. J. (1995). Influence of Bowlby's attachment theory on research on nonhuman primate biobehaviourial development. In S Goldberg, R. Muir and J. Kerr (Eds.), Attachment theory: Social, developmental, and clinical perspectives. Hillsdale, NJ: Analytic Press

Szyf, M., Weaver, I., Provencal, N., McGowan, P. O., Tremblay, R. E. and Meaney, M. J. (2009). Epigenetics and behaviour. In R. E. Tremblay, M. A. G.van Aken and W. Koops (Eds.), Development and prevention of behaviour problems. New York, NY: Psychology Press.

Suomi, S. J. (2009). How gene-environment interactions shape biobehavioural development. In R. E. Tremblay, van M. A. G.Aken and W. Koops (Eds.), Development and prevention of behaviour problems. New York, NY: Psychology Press

Thaler, R., \& Ornstein, C. R. (2008). Nudge. London: Penguin.

Thomson, H. (2010). Empathetic mirror neurons found in humans at last. New Scientist, 2756, 12. doi:10.1016/S0262-4079(10)60911-6

Tilley, N. (Ed.) (2005). Handbook of crime prevention and community safety. Cullompton: Willan.

Tilley, N. (2010). Crime prevention. Cullompton: Willan.

Tooby, J., \& Cosmides, L. (1990). The past explains the present: Emotional adaptations and the structure of ancestral environments. Ethology and Sociobiology, 11, 375-424 doi:10.1016/0162-3095(90)90017-Z

Van Dijk, J. J. M.,\& De Waard, J. (1991). A two-dimensional typology of crime prevention projects: With a bibliography. Criminal Justice Abstracts, 23, 483-503.

Wallace, A. (1986). Homicide: The social reality. Bureau of Crime Statistics and Research. Research Study No. 5. Sydney: BCSR.

Warburton, A. L., \& Sherherd, J. P. (2000). Effects of toughened glassware in terms of reducing injury in bars: A randomized controlled trial. Injury Prevention, 6, 36-40. doi:10.1136/ip.6.1.36

Weldon, S. L. (2002). Protest, policy and the problem of violence against women: A cross-national comparison. Pittsburgh: University of Pittsburgh Press.

Welsh, B., \& Farrington, D. P. (2006). Preventing crime. Dordrecht: Springer. doi:10.1007/1-4020-4244-2

Widom, C. S., \& Brzustowicz, L. M. (2006). MAOA and the "cycle of violence": Childhood abuse and neglect, MAOA genotype, and risk for violent and antisocial behavior. Biological Psychiatry, 60, 684-689. doi:10.1016/j.biopsych.2006.03.039

Wilson, M., \& Daly, M. (1996). Male sexual proprietariness and violence against women. Current Directions in Psychological Science, 5, 2-7. doi:10.1111/1467-8721.ep10772668

Wortley, R. (2011). Psychological criminology. London: Routledge.

Wright, R. (1994). The moral animal: The new science of evolutionary psychology. New York, NY: Pantheon.

Zhong, H. (2005). The age-crime relationship across time and offense types: A comparison of the United States and Taiwan. Doctoral Dissertation. University Park, PA: Pennsylvania State University.

Zimbardo, P. (2007). The lucifer effect: How good people turn evil. London: Rider.

Zimring, F. E., \& Hawkins, G. (1987). The citizen's guide to gun control. London: Macmillan. 